\title{
Development of biofilm of Vibrio alginolyticus for oral immunostimulation of shrimp
}

\author{
S. R. Krupesha Sharma • K. M. Shankar • M. L. Sathyanarayana • \\ Raj Reddy Patil $\cdot$ H. D. Narayana Swamy $\cdot$ Suguna Rao
}

Received: 4 January 2010/Accepted: 26 June 2010/Published online: 11 July 2010

(C) Springer Science+Business Media B.V. 2010

\begin{abstract}
Biofilm (BF) of Vibrio alginolyticus was developed on chitin flakes. BF formation was studied at various nutrient concentrations and incubation time. Highest colonyforming units of BF cells were obtained with $0.15 \%$ trypticase soya broth and at 3 days of incubation. The BF cells could be completely inactivated at $80^{\circ} \mathrm{C}$ in $10 \mathrm{~min}$ and with $10 \%$ formalin in $24 \mathrm{~h}$. SDS-PAGE profile of BF cells revealed repression of four proteins and expression of three new proteins compared to free cells (FC). The preliminary immune response studies showed that BF cells were superior to $\mathrm{FC}$ in stimulating the non-specific immune response of Penaeus monodon.
\end{abstract}

Keywords Vibrio alginolyticus · Penaeus monodon · Biofilm · Free cells · Immunostimulation

$\begin{array}{ll}\text { Abbreviations } \\ \text { TSB } & \text { Trypticase soya broth } \\ \text { CFU } & \text { Colony-forming units } \\ \text { PBS } & \text { Phosphate-buffered saline } \\ \text { TSA } & \text { Trypticase soya agar } \\ \text { TPC } & \text { Total plate count } \\ \text { PMSF } & \text { Phenylmethylsulphonylfloride } \\ \text { RPM } & \text { Rotation per minute }\end{array}$

S. R. Krupesha Sharma - K. M. Shankar · M. L. Sathyanarayana - R. R. Patil ·

H. D. Narayana Swamy · S. Rao

Department of Aquaculture, College of Fisheries, Karnataka Veterinary, Animal and Fisheries

Sciences University, Mangalore 575002, India

M. L. Sathyanarayana · H. D. Narayana Swamy · S. Rao

Department of Pathology, Veterinary College, Hebbal, Bangalore 560024, India

S. R. Krupesha Sharma $(\bowtie)$

Karwar Research Centre of Central Marine Fisheries Research Institute (Indian Council of Agricultural

Research), P.B.No.5, Karwar 581301, India

e-mail: krupeshsharma@gmail.com 


$\begin{array}{ll}\text { EDTA } & \text { Ethylene diamine tetraacetic acid } \\ \text { THC } & \text { Total haemocyte count } \\ \text { PO } & \text { Phenoloxidase activity } \\ \text { L-DOPA } & \text { L-dihydroxyphenylalanine } \\ \text { ANOVA } & \text { Analysis of variance } \\ \text { BF } & \text { Biofilm } \\ \text { FC } & \text { Free cell } \\ \text { SDS-PAGE } & \text { Sodium dodecyl sulfate-polyacrylamide gel electrophoresis } \\ \text { SD } & \text { Standard deviation }\end{array}$

\section{Introduction}

Use of immunostimulants is an effective means of increasing the immunocompetency and disease resistance in fish (Sakai 1999). Furthermore, oral stimulation of immune system is most economical and practical strategy in commercial culture of fish and shrimp. However, one of the important factors for the inconsistency and poor response to oral vaccination in fish is the digestive degradation of antigens in the foregut before the vaccine reaches immune responsive areas in the hindgut and other lymphoid organs (Azad et al. 2000). Bacterial biofilms, which are growing colony of bacteria on a substrate enveloped by glycocalyx (Costerton et al. 1981), are reported to be highly resistant to antibiotics (Brown et al. 1988), surfactants (Govan 1975) and antibodies (Kreig et al. 1988). Higher protective immune response in the form of elevated antibody titres was reported in common carp administered orally BF cells of Aeromonas hydrophila (Azad et al. 1999), which was attributed to superior antigen delivery to the lymphoid tissues as evidenced by antigen localization using monoclonal antibodies (Azad et al. 2000).

Changes in the protein profile of BF cells in comparison with free cells (FC) of A. hydrophila used in oral vaccination of fish have been reported (Asha et al. 2004). Cellsurface structures, cell wall composition, exopolysaccharide and capsular polysaccharides present in the bacteria vary with growth conditions. Bacteria infecting tissues produce cellsurface components not found on the bacteria grown in vitro (Brown and Williams 1985), and cell-surface changes may be produced in the cells of same species in response to variations in nutrient status, surface growth and other environmental factors (Lorian et al. 1985).

As shrimp lack specific immune response involving memory, there is need for oral immunostimulation that is long lasting and resistant to gut destruction. By considering the advantage of BF as a vaccine in teleost fish, we developed BF of Vibrio alginolyticus with an objective to standardize the biofilm development in vitro and test its expediency as an immunostimulant in P. monodon. There are no published reports on the application of BF as an immunostimulant in shrimp culture.

\section{Materials and methods}

Source of $V$. alginolyticus

The bacteria were obtained from an infected P.monodon from a culture pond at Vypeen near Kochi, Kerala, India during June 2006 by isolating on 1.5\% TSB (Himedia, Mumbai) 
containing $2 \% \mathrm{NaCl}$ and identified based on biochemical characteristics. The isolate was preserved in $1.5 \% \mathrm{TSB}$ containing $0.15 \%$ glycerol at $-20^{\circ} \mathrm{C}$. For use, an aliquot was revived on nutrient agar slant and stored at $4^{\circ} \mathrm{C}$.

\section{Nutrient requirement for $\mathrm{BF}$ formation}

Ideal concentration of nutrients for optimum BF formation was standardized according to Azad et al. 1997. Six concentrations of TSB (0.025, 0.05, 0.1, 0.15, 0.2 and $0.25 \%)$ in duplicate were prepared and supplemented with $2 \% \mathrm{NaCl}$. Chitin $(0.3 \%, \mathrm{~W} / \mathrm{V})$, as substrate, was added to each flask and autoclaved. Culture of $V$. alginolyticus in log phase $\left(1 \mathrm{X} 10^{7} \mathrm{CFU}\right)$ in $1.5 \% \mathrm{TSB}$ was inoculated to each flask and incubated at room temperature for $24 \mathrm{~h}$ with 6-h agitation at 120 strokes $\mathrm{min}^{-1}$ on a mechanical shaker. After incubation, the supernatant solution was decanted into six sterile flasks. Chitin was washed thrice in sterile PBS ( $\mathrm{pH}$ 7.4) by gently swirling the flask thrice, and the supernatant with loosely bound cells was decanted. Chitin was then transferred to 50-ml centrifuge tubes containing $10 \mathrm{ml}$ PBS and agitated for $4 \mathrm{~min}$ on a cyclomixer to dislodge the BF cells. Dislodged cells were serially diluted in sterile saline and inoculated to TSA plates in triplicate by surface spread technique. TPC was obtained after incubation at room temperature for $24 \mathrm{~h}$, and the counts were expressed as mean $\mathrm{CFU} \mathrm{g} \mathrm{g}^{-1}$ chitin. The decanted supernatant solutions in sterile flasks were serially diluted in sterile saline after harvesting and washing twice in PBS. The diluted samples were inoculated to TSA plates in triplicate. Viable counts of FC were determined after incubating the plates at room temperature for $24 \mathrm{~h}$ and expressed as mean CFU ml $^{-1}$.

\section{Period of incubation for optimum BF formation}

For studying the bacterial kinetics, culture of $V$. alginolyticus in log phase (1X10 $\left.70^{7} \mathrm{CFU}\right)$ was inoculated to five flasks in duplicate containing 0.15\% TSB (supplemented with $2 \%$ $\mathrm{NaCl}$ ) and $0.3 \%$ chitin and incubated for five days at room temperature with $6 \mathrm{~h}$ of shaking day $^{-1}$ on a mechanical shaker. Duplicate plates were removed at the end of every $24 \mathrm{~h}, \mathrm{BF}$ and FC were harvested, and TPC was determined.

\section{Heat and chemical inactivation of BF cells}

For standardizing heat and chemical inactivation of BF cells, three-day-old BF cells (as per the results of the bacterial kinetics study) grown in $0.15 \%$ TSB containing $0.3 \%$ chitin were harvested and placed in water bath at 60,70 and $80^{\circ} \mathrm{C}$ for 10 and $20 \mathrm{~min}$. The samples were then plated on TSA plates, and per cent inactivation was enumerated. Oneday-old FC in $1.5 \%$ TSB were harvested and placed in a water bath at 60,70 and $80^{\circ} \mathrm{C}$ for 10 and 20 min after which the samples were plated on TSA plates and per cent inactivation was enumerated.

Three-day-old BF grown in $0.15 \%$ TSB containing $0.3 \%$ chitin was harvested and incubated in PBS containing 1, 5 and 10\% formalin for 12, 24 and $48 \mathrm{~h}$. One-day-old FC in $1.5 \%$ TSB were harvested and incubated in PBS containing $0.5 \%$ formalin for $24 \mathrm{~h}$. After the incubation period, samples were plated on TSA plates and incubated for $24 \mathrm{~h}$ at room temperature, and per cent inactivation was enumerated. 
SDS-PAGE analysis of BF and FC

Protein profile of $V$. alginolyticus BF and FC was analysed using SDS-PAGE according to Laemmli 1970. Three-day-old BF of V. alginolyticus on chitin was harvested by vortex mixing in PBS with $1 \mathrm{mM}$ PMSF (Sigma, USA). The BF mass was pelleted after centrifugation at $86,400 \mathrm{~g}$ for $30 \mathrm{~min}$ at $4^{\circ} \mathrm{C}$. One-day-old FC of $V$. alginolyticus were centrifuged at 7,100 $\mathrm{g}$ for $10 \mathrm{~min}$, and cells were harvested and washed thrice in sterile PBS ( $\mathrm{pH}$ 7.2). The samples were solubilized in reducing buffer and vortexed well. The solutions were then boiled at $100^{\circ} \mathrm{C}$ for $1 \mathrm{~min}$ and spun at 5,000 rpm for 2 min to settle down the debris. Protein content of the harvested BF and FC was analysed (Bradford, 1976). Twenty microlitres of sample supernatants containing $10 \mu \mathrm{g}$ protein was loaded onto $4.5 \%$ stacking gel along with the protein marker (Sigma, USA) and resolved in a $15 \%$ separating gel at $150 \mathrm{~V}$ in a mini gel electrophoretic system. After electrophoresis, the resolved protein bands were visualized in coomassie brilliant blue $(0.1 \%$ (W/V) in $40 \%$ methanol and $10 \%$ glacial acetic acid), stained for $1 \mathrm{~h}$ followed by destaining in $40 \%$ methanol and $10 \%$ glacial acetic acid till the background was clear.

Source, maintenance and feeding of P. monodon

Juvenile $P$. monodon ( $1.6 \pm 0.3 \mathrm{~g}$ ), obtained from Matsya fed prawn hatchery, Kannur, India, were acclimatized in the laboratory for 15 days in sea water (salinity $30 \pm 1 \%$; $\mathrm{pH} 7.6 \pm 0.2$; temperature $26 \pm 0.2^{\circ} \mathrm{C}$ ) with continuous aeration. For the experiment, shrimp were divided into three groups and maintained in plastic tubs with triplicate tubs for each group containing 801 sea water (salinity $30 \pm 1 \%$; pH $7.6 \pm 0.2$; temperature $26 \pm 0.5^{\circ} \mathrm{C}$ ) with continuous aeration. Each tub was stocked with 10 shrimp. Required concentration of heat-inactivated BF cells on chitin flakes and heat-inactivated FC with autoclaved chitin was uniformly mixed with commercial shrimp feed with the help of a binder (Protogel, Orgavet Pharma, Vijayawada, India). First group was fed with BF cells at $10^{8} \mathrm{cfu}^{-1}$ shrimp day ${ }^{-1}$ through feed for 7 days. Second group was fed with FC at $10^{8}$ $\mathrm{cfu}^{-1}$ shrimp day ${ }^{-1}$ through feed for 7 days. Shrimp in the third group, which received standard shrimp feed containing autoclaved chitin flakes, constituted the control group. Shrimp were fed at $5 \%$ of body weight twice daily. On day 8 , haemolymph samples were collected from individual shrimp in their inter-moult stage directly from the heart using a tuberculin syringe fitted to a 26-gauge needle. When haemolymph collected from a single individual was not sufficient to fulfil analysis requirement, samples collected from 2 to 3 shrimp were pooled. Haemolymph $(300 \mu \mathrm{l})$ was collected in $700 \mu \mathrm{l}$ of marine anticoagulant solution (0.01 M trisodium citrate, $0.34 \mathrm{M}$ sodium chloride, $10 \mathrm{mM}$ EDTA, $0.12 \mathrm{M}$ glucose, $\mathrm{pH}$ 7.4) and subjected to enumeration of THC and PO activity (Liu and Chen 2004).

\section{Enumeration of THC}

A drop of the haemolymph-anticoagulant mixture was dispensed on a Neubauer slide, and the cells were allowed to settle for few seconds. The cells were counted in all five large squares and expressed as cells $\mathrm{ml}^{-1}$ of haemolymph.

\section{Enumeration of PO activity}

PO activity was measured spectrophotometrically by recording the formation of dopachrome from L-DOPA. Diluted haemolymph was centrifuged at $700 \mathrm{~g}$ at $4{ }^{\circ} \mathrm{C}$ for $10 \mathrm{~min}$. 
After discarding the supernatant, the pellet was rinsed, resuspended gently in cacodylatecitrate buffer $(0.01 \mathrm{M}$ sodium cacodylate, $0.45 \mathrm{M}$ sodium chloride, $0.10 \mathrm{M}$ trisodium citrate, and $\mathrm{pH} 7.0$ ) and centrifuged again. The pellet was resuspended in $600 \mu$ l cacodylate buffer $(0.01 \mathrm{M}$ sodium cacodylate, $0.45 \mathrm{M}$ sodium chloride, $0.01 \mathrm{M}$ calcium chloride, $0.26 \mathrm{M}$ magnesium chloride, and $\mathrm{pH} 7.0$ ), and $100 \mu \mathrm{l}$ of the cell suspension was incubated with $50 \mu \mathrm{l}$ of trypsin $\left(1 \mathrm{mg} \mathrm{ml}^{-1}\right)$, which served as an elicitor, for $10 \mathrm{~min}$ at $20^{\circ} \mathrm{C}$. Fifty $\mu \mathrm{l}$ of L-DOPA ( $3 \mathrm{mg} \mathrm{ml}^{-1}$ ) as a substrate was then added, and $800 \mu \mathrm{l}$ of cacodylate buffer was added $5 \mathrm{~min}$ later. The optical density at $490 \mathrm{~nm}$ was measured using a Varion Carry50 spectrophotometer. The PO activity was expressed as $\delta$ (490) $50^{-1} \mu \mathrm{l}$ of haemolymph. The control solution that consisted of $100 \mu \mathrm{l}$ of cell suspension, $50 \mu \mathrm{l}$ cacodylate buffer (to replace trypsin) and $50 \mu \mathrm{l}$ of L-DOPA was used for background PO activity. The background PO activity, which ranged from 0.02 to 0.08 , was subtracted from the PO activity of shrimp for all test conditions.

Statistical analysis

CFU, THC and PO activity values were expressed as mean \pm SD. The mean values of nutrient requirement for optimum $\mathrm{BF}$ formation and growth kinetics were statistically analysed by one-way ANOVA with tukey post-tests using GraphpadPrism (Version: 4) for Windows, GraphPad Software, San Diego, California, USA. THC and PO values were analysed by performing two-Way ANOVA with Bonferroni post-tests using GraphpadPrism (Version: 4) for Windows, GraphPad Software, San Diego, California, USA.

\section{Results}

Among six nutrient concentrations studied, significantly $(P<0.001)$ higher $\mathrm{CFU}$ of BF cells were obtained with $0.15 \%$ TSB supplemented with $2 \% \mathrm{NaCl}$ (Fig. 1). Highest CFU $\mathrm{g}^{-1}$ of chitin flakes was obtained on third day of incubation that was significantly $(P<0.001)$ higher than the CFU on 1, 2, 4 and 5 days (Fig. 2). Highest CFU ml ${ }^{-1}$ of FC was obtained on second day of incubation.

Complete inactivation of 3-day-old $\mathrm{BF}$ was achieved at $80^{\circ} \mathrm{C}$ for $10 \mathrm{~min}$, whereas complete inactivation of $\mathrm{FC}$ was possible at $60^{\circ} \mathrm{C}$ for $10 \mathrm{~min}$ (Table 1). In case of formalin inactivation, complete inactivation of BF cells was achieved with $10 \%$ formalin in $24 \mathrm{~h}$, while FC were completely inactivated with $0.5 \%$ formalin in $24 \mathrm{~h}$ (Table 2).

Fig. 1 Growth of BF and FC of $V$. alginolyticus under different nutrient concentrations (vertical bars indicate SD)

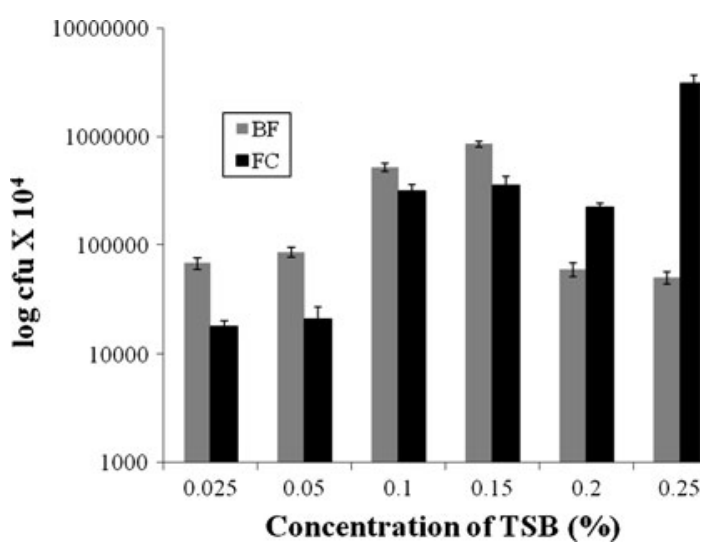

Springer 
Fig. 2 Growth kinetics of V. alginolyticus $\mathrm{BF}$ and $\mathrm{FC}$ (vertical bars indicate $\mathrm{SD}$ )

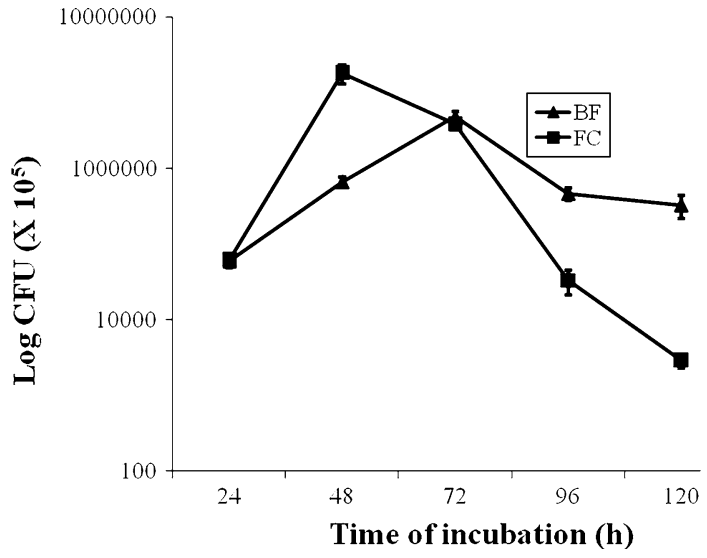

Table 1 Heat inactivation of three-day-old BF and one-day-old FC of V. alginolyticus

\begin{tabular}{lllllll}
\hline BF cells & & & & FC & \\
\cline { 1 - 1 } Temp $\left({ }^{\circ} \mathrm{C}\right)$ & Time $(\mathrm{min})$ & \% Inactivation & & Temp $\left({ }^{\circ} \mathrm{C}\right)$ & Time $(\mathrm{min})$ & \% Inactivation \\
\hline 60 & 10 & 91.26 & & 60 & 10 & 99.99 \\
60 & 20 & 96.76 & & 60 & 20 & 99.99 \\
70 & 10 & 99.46 & & 70 & 10 & 99.99 \\
70 & 20 & 99.96 & & 70 & 20 & 99.99 \\
80 & 10 & 99.99 & & 80 & 10 & 99.99 \\
\hline
\end{tabular}

Table 2 Formalin inactivation of three-day-old BF and one-day-old FC of $V$. alginolyticus

\begin{tabular}{lllll}
\hline \% Formalin & \multicolumn{3}{l}{ \% Inactivation of FC after } & \multicolumn{3}{l}{$\%$ Inactivation of BF cells after } \\
\cline { 3 - 5 } & $24 \mathrm{~h}$ & $12 \mathrm{~h}$ & $24 \mathrm{~h}$ & $48 \mathrm{~h}$ \\
\hline 0.5 & 99.99 & $\mathrm{~N}$ & $\mathrm{~N}$ & $\mathrm{~N}$ \\
1 & $\mathrm{~N}$ & $\mathrm{~N}$ & $\mathrm{~N}$ & 92.22 \\
5 & $\mathrm{~N}$ & 96.66 & 99.22 & 99.99 \\
10 & $\mathrm{~N}$ & 99.92 & 99.99 & $\mathrm{~N}$ \\
\hline
\end{tabular}

$N$ Not tested

SDS-PAGE of 3-day-old BF and FC revealed the separation of a total of 22 proteins from FC. With BF cells, an additional expression of three proteins of 45, 50 and $55 \mathrm{kDa}$ was recorded. Furthermore, a repression of four proteins of 31, 44, 47 and $53 \mathrm{kDa}$ was also found (Fig. 3).

Mean values of both THC and PO activity were significantly $(P<0.001)$ higher in BF group on day 7 when compared to FC fed or control shrimp (Fig. 4). Also, values of THC and PO activity were significantly $(P<0.001)$ higher on day 7 compared to that on day zero in both $\mathrm{BF}$ and $\mathrm{FC}$ groups. 
Fig. 3 SDS-PAGE profile of BF and $\mathrm{FC}$ of $V$. alginolyticus: grey lines on the left indicate repressed proteins, black lines indicate newly expressed proteins

Fig. 4 Mean immune response values of $P$. monodon fed with $\mathrm{BF}$ and $\mathrm{FC}$ of $V$. alginolyticus: $a$ THC; $b$ PO activity (vertical bars indicate $\mathrm{SD}$; means with common letters have significant difference between them, $P<0.001)$
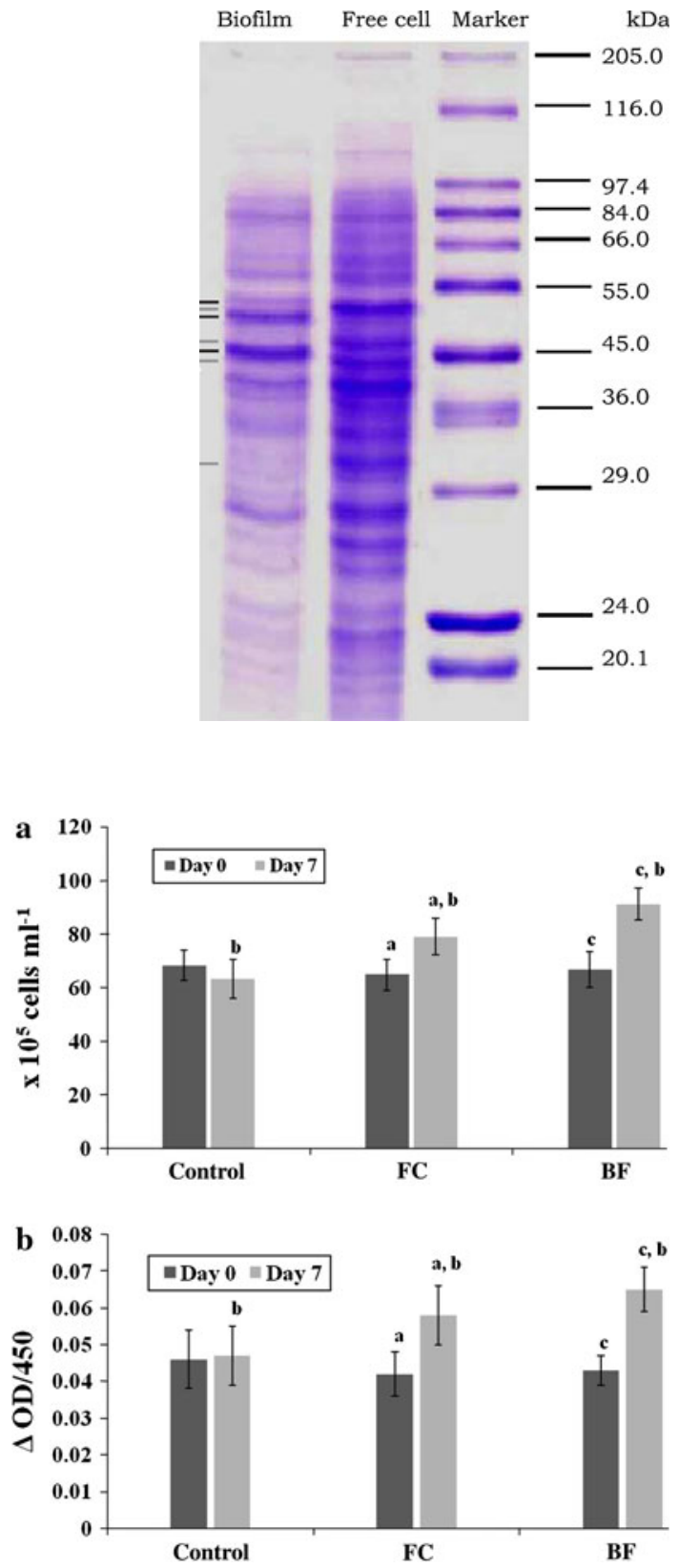

\section{Discussion}

Among various TSB concentrations studied, highest CFU of BF cells was obtained with $0.15 \%$ supplemented with $2 \% \mathrm{NaCl}$. Azad et al. 1997 used four different concentrations of TSB and obtained highest CFU of BF cells of A. hydrophila with $0.225 \%$ TSB concentration. Bacterial kinetics showed that increased colonization with time resulted in an 
increase in BF population with a corresponding decrease in population of FC. Similar observations were reported in case of Staphylococcus aureus (Anwar et al. 1992) and A. hydrophila (Azad et al. 1999).

Three-day-old BF cells were completely inactivated at $80^{\circ} \mathrm{C}$ in $10 \mathrm{~min}$ and $10 \%$ formalin in $24 \mathrm{~h}$. In contrast, $\mathrm{FC}$ of $\mathrm{V}$. alginolyticus were completely inactivated at $60^{\circ} \mathrm{C}$ in $10 \mathrm{~min}$ and $0.5 \%$ formalin in $24 \mathrm{~h}$. BF cells of $A$. hydrophila were completely inactivated at $90^{\circ} \mathrm{C}$ in $30 \mathrm{~min}$ (Azad et al. 1999). The present study revealed that BF cells of $V$. alginolyticus were more resistant to heat and chemical treatment compared to FC. Role of $\mathrm{BF}$ as barriers of heat exchange has been reported. Bacteria have been known to colonize water-cooled metal surfaces in heat exchangers, resulting in reduced thermal exchange abilities. Aged BF cells embedded in multilayered glycocalyx are shielded against heat and chemical action, and hence, the cells in the deeper layers survive (Costerton et al. 1981).

With BF cells, an additional expression of three proteins and repression of four proteins were observed. BF cells of $A$. hydrophila showed repression of nine proteins and additional expression of three proteins of 72, 36 and $22 \mathrm{kDa}$ (Asha et al. 2004). Similar observations were also made in Pseudomonas putida where 15 proteins were up-regulated and 30 proteins were down-regulated following attachment to silicon surface (Sauer and Camper 2001). Another related study under iron-limited conditions has shown that $P$. aeruginosa expressed additional 77 and $85 \mathrm{kDa}$ proteins (Anwar et al. 1984). BF of P. aeruginosa developed on glass wool also revealed changes in protein profile (Steym et al. 2001). Studies on starved cells of $A$. hydrophila have shown that about five outer membrane proteins were lost with the expression of three new proteins compared to FC (Rahman et al. 1998). Also, starved cells of Vibrio sp. lost many cellular proteins and synthesized new proteins called starvation proteins (Amy and Morita 1983; Nelson et al. 1997). Expression of additional proteins in BF cells could be a stress response, which might help the bacteria to survive in the new mode of life (Buchmeier and Hefron 1990).

$\mathrm{BF}$ of $V$. alginolyticus could stimulate the immune response of $P$. monodon as evidenced by elevated THC and PO activity. Also, BF cells were found superior to FC in stimulating the immune response. This might be due to the better delivery of antigen from $\mathrm{BF}$, since the cells are embedded in the glycocalyx matrix thus facilitating a slow and sustained release of antigens when compared to FC antigens that are normally rapidly digested and released resulting in short-lived and insufficient immune activation (Azad et al. 1999). Improved antigen delivery and protective responses in carp administered BF cells of A. hydrophila by oral route have been demonstrated (Azad et al. 2000). Elevated THC and PO activity were also reported when shrimp were administered various immunostimulants like probiont bacterium (Rengpipat et al.2000), $\beta$-1, 3-glucan (Lopez et al. 2003), spent brewer's yeast $\beta$-glucan (Suphantharika et al. 2003), chitin/chitosan (Wang and Chen 2005), Sargassum fusiforme polysaccharide extracts (Huang et al. 2006) and marine yeast (Sajeevan et al. 2006).

In the present study, heat-inactivated BF cells were used as oral immunostimulant, since large number of immunogenic epitopes were expressed leading to higher protective response in heat-inactivated bacterin than formalin-inactivated cells (Lamers and van Muiswinkel 1986).

Present study established that $V$. alginolyticus BF can be developed on chitin flakes. BF cells were found to be more resistant to heat and chemical action when compared to FC. Also, BF cells showed changes in protein profile when compared to FC. Preliminary immune response studies showed that BF cells were superior to FC in stimulating the immune system of P. monodon. 
Acknowledgments The study formed part of the Ph.D work of the first author. The first author is indebted to the Director, C.M.F.R.I. for granting study leave to pursue Ph.D work.

\section{References}

Amy PS, Morita RY (1983) Protein patterns of growing and starved cells of a marine Vibrio sp. Appl Environ Microbiol 45:1685-1696

Anwar H, Brown MRW, Day A, Weller P (1984) Outer membrane antigens of mucoid Pseudomonas aeruginosa isolated directly from the sputum of a cystic fibrosis patient. FEMS Microbiol Lett 24:235-239

Anwar H, Strap JL, Costerton JW (1992) Susceptibility of BF cells of Pseudomonas aeruginosa to bactericidal actions of whole blood serum. FEMS Microbiol Lett 92:242-253

Asha A, Nayak DT, Shankar KM, Mohan CV (2004) Antigen expression in biofilm cells of Aeromonas hydrophila employed in oral vaccination of Fish. Fish Shellfish Immunol 16:429-436

Azad IS, Shankar KM, Mohan CV (1997) Evaluation of biofilm of Aeromonas hydrophila for oral vaccination of carps. In: Flegel TW, Macrae IH (eds) Diseases in Asian aquaculture III. Fish Health Section, AFS, Manila, pp 181-186

Azad IS, Shankar KM, Mohan CV, Kalita B (1999) Biofilm vaccine of Aeromonas hydrophila-standardization of dose and duration for oral vaccination of carps. Fish Shellfish Immunol 9:519-528

Azad IS, Shankar KM, Mohan CV, Kalita B (2000) Uptake and processing of biofilm and free-cell vaccines of Aeromonas hydrophila in Indian major carps and common carp following oral vaccination-antigen localization by a monoclonal antibody. Dis Aquat Org 43:103-108

Bradford MM (1976) A rapid and sensitive method for the quantification of microgram quantities of protein utilizing the principle of protein-dye binding. Anal Biochem 72:248-254

Brown MRW, Williams P (1985) The influence of environment on envelop properties affecting survival of bacteria in infections. Annu Rev Microbiol 39:521-527

Brown MRW, Allison DG, Gilbert P (1988) Resistance of bacterial biofilms to antibiotics: a growth rate related effect? J Antimicrob Chemother 22:777-780

Buchmeier NA, Hefron F (1990) Induction of Salmonella stress proteins upon infection of macrophages. Science 248:730-732

Costerton JW, Irwin RT, Cheng KJ (1981) The bacterial glycocalyx in nature and disease. Annu Rev Microbiol 35:299-324

Govan JRW (1975) Mucoid strains of Pseudomonas aeruginosa: the influence of culture medium on the stability of mucus production. J Med Microbiol 8:513-522

Huang X, Zhou H, Zhang H (2006) The effect of Sargassum fusiforme polysaccharide extracts on vibriosis resistance and immune activity of the shrimp, Fenneropenaeus chinensis. Fish Shellfish Immunol 20:750-757

Kreig DP, Helmke RJ, German VF, Mangos JA (1988) Resistance of mucoid Pseudomonas aeroginosa to non-opsonic phagocytosis by alveolar macrophages in vitro. Infect Immunol 56:3173-3179

Laemmli UK (1970) Cleavage of structural proteins during assembly of the head of bacteriophage T4. Nature 227:680-685

Lamers CHJ, van Muiswinkel WB (1986) Natural and acquired agglutinins to Aeromonas hydrophila in carp (Cyprinus caprio). Can J Fish Aquat Sci 43:619-624

Liu CH, Chen JC (2004) Effect of ammonia on the immune response of white shrimp Litopenaeus vannamei and its susceptibility to Vibrio alginolyticus. Fish Shellfish Immunol 16:321-334

Lopez N, Cuzon G, Gaxiola G, Taboada G, Valenzuela M, Pascual C, Sanchez A, Rosas C (2003) Physiological, nutritional, and immunological role of dietary $\beta$ 1-3 glucan and ascorbic acid 2-monophosphate in Litopenaeus vannamei juveniles. Aquaculture 224:223-243

Lorian V, Zak O, Suter J, Bruechrer C (1985) Staphalococci-in vitro and in vivo. Diagn Microbiol Infect Dis 3:433-444

Nelson RD, Sadlowski Y, Eguchi M, Kjelleberg S (1997) The starvation stress response of Vibrio (Listonella) anguillarum. Microbiol 143:2305-2312

Rahman MH, Suzuki S, Kusuda R, Kawai K (1998) Changes of outer membrane and S-layer protein profiles of Aeromonas hydrophila by starvation. Fish Pathol 33:275-279

Rengpipat S, Rukpratanporn S, Piyatiratitivorakul S, Menasaveta P (2000) Immunity enhancement in black tiger shrimp (Penaeus monodon) by a probiont bacterium (Bacillus S11). Aquaculture 191:271-288

Sajeevan TP, Philip R, Singh ISB (2006) Immunostimulatory effect of a marine yeast Candida sake S165 in Fenneropenaeus indicus. Aquaculture 257:150-155 
Sakai M (1999) Current research status of fish immunostimulants. Aquaculture 172:63-92

Sauer K, Camper AK (2001) Characterization of phenotypic changes in P. putida in response to surfaceassociated growth. J Bacteriol 183:6579-6589

Steym B, Oosthuizen MC, MacDonald Theron J, Brozel VS (2001) The use of glass wool as an attachment surface for studying phenotypic changes in Pseudomonas aeruginosa biofilms by two-dimensional gel electrophoresis. Proteomics 1:871-879

Suphantharika M, Khunrae P, Thanardkit P, Verduyn C (2003) Preparation of spent brewer's yeast $\beta$ glucans with a potential application as an immunostimulant for black tiger shrimp, Penaeus monodon. Bioresour Technol 88:55-60

Wang SH, Chen JC (2005) The protective effect of chitin and chitosan against Vibrio alginolyticus in white shrimp Litopenaeus vannamei. Fish Shellfish Immunol 19:191-204 